\title{
ECOLOGICAL RISK ASSESSMENT OF HEAVY METALS IN SEDIMENTS OF A RIVERINE WETLAND, HUAIHE RIVER WATERSHED, CHINA
}

\author{
OCENY RYZYKA EKOLOGICZNEGO ZWIAZZANEGO \\ Z METALAMI CIĘŻKIMI W OSADACH NADRZECZNYCH TERENÓW \\ PODMOKŁYCH ZLEWNI RZEKI HUAIHE, CHINY
}

\begin{abstract}
The concentrations of $\mathrm{Zn}, \mathrm{Cr}, \mathrm{Cu}, \mathrm{As}, \mathrm{Cd}$, and $\mathrm{Pb}$ in sediment cores collected from a representative riverine wetland located in the Huaihe River watershed, China, dramaticlly increased from the bottom to upper layer of the cores. Application of principal component analysis (PCA) and enrichment factor (EF) suggested that heavy metals might primarily have been derived from the inflow of contaminated water from an industrial park and agricultural region. Component 1 of the PCA was dominated by $\mathrm{Zn}, \mathrm{Cr}, \mathrm{Cu}, \mathrm{Cd}$, and $\mathrm{Pb}$, while Component 2 was dominated by As. Metals' high concentrations and $E F$ values showed that the anthropogenic pollutants have increased sharply in recent years and reflect the continuous development of industry and agriculture in the region of the wetland, with a corresponding dramatic deterioration of the environment due to constant effluent of pollutants. Cd exerted the highest potential ecological risk of individual metals of sediment cores. Additionally, integrated $R I$ values for all metals indicated that sediments possessed low ecological risk from the bottom to about $6 \mathrm{~cm}$ depth of the cores, moderate ecological risk from about $5 \mathrm{~cm}$ depth upwards, then considerable ecological risk from $4 \mathrm{~cm}$ depth to the top layer of the sediment cores, which demonstrates a continuous deterioration of environmental quality in recent years in this region.
\end{abstract}

Keywords: environmental geochemistry characteristics, ecological risk assessment, heavy metals, sediments, riverine wetland

\section{Introduction}

Contamination from heavy metals has become a worldwide environmental concern due to their persistence and bioaccumulation and for causing serious environmental problems to the human environment [1-3]. In an aquatic system, heavy metals can migrate from the water to sediments and some of these pollutants can be desorbed from the sediments and

\footnotetext{
${ }^{1}$ Jiangsu Key Laboratory of Atmospheric Environment Monitoring and Pollution Control and Collaborative Innovation Center of Atmospheric Environment and Equipment Technology (CICAEET), School of Environmental Science and Engineering, Nanjing University of Information Science \& Technology, 210044 Nanjing, P. R. China, phone +86 2558731430

${ }^{2}$ School of Life Science and Institute of Wetland Ecology, Nanjing University, 210093 Nanjing, P. R. China

*Corresponding author: yuanhezhong@126.com (H. Z. Yuan); anshq@nju.edu.cn (S.Q. An)
} 
ingested by the biota [4]. Heavy metals from anthropogenic sources such as industry wastewater, domestic sewage, and atmospheric deposition can be accumulated in the sediments of rivers, lakes, and wetlands, etc. The persistence and toxicity of heavy metals make them environmental hazards [5, 6]. Analysis of heavy metals in the sediment can be helpful for understanding their anthropogenic sources, deposition processes, and potential ecological risk.

Over the last few decades, China had undergone a rapid and extensive industrial growth, and heavy metal pollution in aquatic ecosystems arose correspondingly [7-10]. The Huaihe River is one of the most important rivers in East China. The upper reach of the Huaihe River Watershed is located in Henan Province and flows across extensive industrial and agricultural areas. With the rapid growth of the region's economy and urbanization, more and more wastes were discharged into the Huaihe River and its tributaries [11]. However, only a few studies are available on systemic investigation and assessment for distribution of accumulated heavy metals in sediments of riverine wetlands in the Huaihe River Watershed, which records the historical pollution process and biogeochemical recycling for heavy metals in the riverine area $[12,13]$. The purposes of this research are to (1) survey the variation of heavy metals in different depths of sediments, (2) evaluate the sources and temporal patterns of pollution from heavy metals, and (3) assess the potential ecological risk of heavy metals in aquatic ecosystems of a representative riverine wetland.

\section{Methods and materials}

\section{Collection of samples}

Three parallel sediment cores were taken from a riverine wetland located near the Suoxu River $\left(34^{\circ} 51^{\prime} 40^{\prime \prime} \mathrm{N}, 113^{\circ} 33^{\prime} 31^{\prime \prime} \mathrm{E}\right)$, an important tributary of the Huaihe River, using a columnar sampling instrument in April of 2013 (Fig. 1).

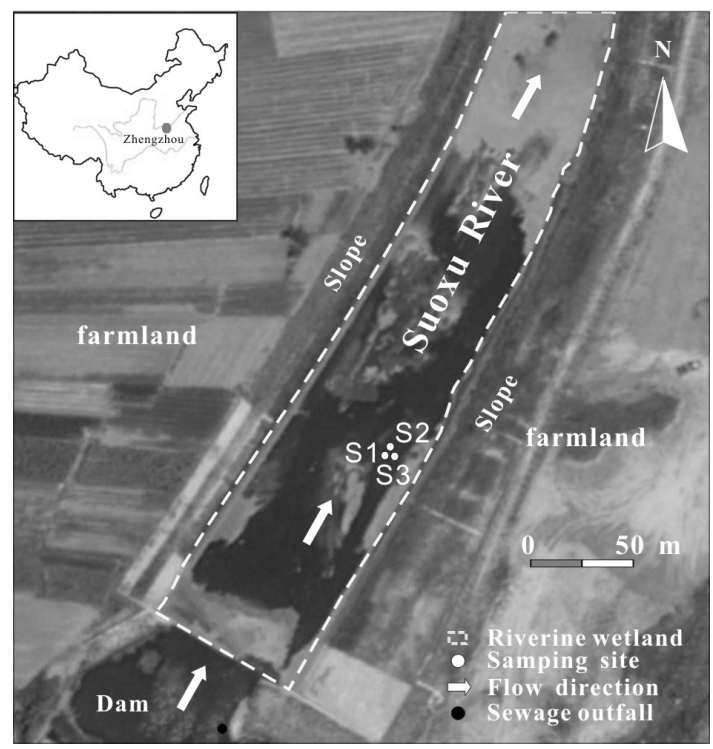

Fig. 1. Schematic of research area and location of sampling sites 
The obtained cores, down to a depth of $8 \mathrm{~cm}$, were sliced into sub-samples at $1 \mathrm{~cm}$ intervals. The common physicochemical properties included temperature $(\mathrm{T}), \mathrm{pH}$, total dissolved solids (TDS), redox potential (ORP), electric conductivity (EC), and dissolved oxygen (DO) concentration, were determined by a Multi-parameter Water Quality Analyzer (HORIBA U-50, Japan). The sub-samples were immediately placed into sealed plastic bags and stored at a temperature of $4^{\circ} \mathrm{C}$ until analysis. After vacuum freeze-drying, the sediment sub-samples were ground using an agate mortar and pestle and then sieved with a standard 100 mesh sieve for analysis. The overlying water samples were concurrently collected at each sampling site and transported immediately to the laboratory for analysis.

\section{Analysis of samples}

The ammonium $\left(\mathrm{NH}_{4}{ }^{+}\right)$, nitrate $\left(\mathrm{NO}_{3}{ }^{-}\right)$, total nitrogen (TN), total phosphorus (TP) and phosphate $\left(\mathrm{PO}_{4}{ }^{3-}\right)$ concentrations in the water samples were determined in the laboratory [14]. Generally speaking, $\mathrm{NH}_{4}{ }^{+}$concentration was measured using a spectrophotometric method with salicylic acid, TP concentration was measured with a ammonium molybdate spectrophotometric method, $\mathrm{TN}$ and $\mathrm{NO}_{3}^{-}$concentrations were analyzed by using an ultraviolet spectrophotometry, and $\mathrm{PO}_{4}{ }^{3-}$ concentration was determined with a molybdenum-antimony anti-spectrophotometric method.

Additionally, about $0.5 \mathrm{~g}$ of dried sediment was digested with $\mathrm{HCl}-\mathrm{HNO}_{3}-\mathrm{HClO}_{4}$. Then the concentrations of $\mathrm{Fe}, \mathrm{Al}, \mathrm{Ca}$, and $\mathrm{Mn}$ were analyzed by inductively coupled plasma atomic emission spectrometry (ICP-AES Profile DV, Leeman Labs, USA). Zn, Cr, Cu, As, $\mathrm{Cd}$, and $\mathrm{Pb}$ concentrations were determined by inductively coupled plasma mass spectrometry (ICP-MS 7700x, Agilent Technologies, USA). Certified reference material CL-CAL-2 was supplied by the SPEX CertiPrep Group, USA. The analytical error was within $\pm 6 \%$ of the certified values for all six metals.

About $0.1 \mathrm{~g}$ of dry sediment was digested with $5 \% \mathrm{HCl}$ to remove carbonate. The total organic carbon (TOC) and total nitrogen (TN) were determined with a CHNO-S elemental analyzer (Leeman Company, USA). TOC and TN radio (reported as $\mathrm{C} / \mathrm{N}$ ) was calculated subsequently.

\section{Multivariate analysis methods}

The enrichment factor $(E F)$ for heavy metals has been widely used to assess human contamination $[15,16]$. It was calculated by using the modified formula proposed by Glasby et al [17]:

$$
E F=\left[C_{x} / C_{r}\right]_{\text {sample }} /\left[C_{x} / C_{r}\right]_{\text {background }}
$$

where $C_{x}$ refers to the concentration of an analysed element and $C_{r}$ is the concentration of the reference elements in the samples and background, respectively.

The concentrations of elements in the Earth's crust are commonly chosen as the background values [18]. Fe was considered as the "conservative" element and has been commonly chosen as a reference element [19].

Principal component analysis (PCA) has been widely applied to assess the sources and original variables of the contaminants by reason of reduction in the dimensionality of the variables and integration in the majority of parameters with lesser factors combined with knowledge of activities in the researched region [20-22]. The resulting clusters help identify 
relatively homogeneous groups of variables [23]. For our study, SPSS 13.0 software for Windows (SPSS Inc., USA) was used for the PCA and correlation analyses of the variables.

\section{Ecological risk assessment}

The potential ecological risk index (ERI) was initially proposed by Håkanson [24] and is used in ecological risk assessments of heavy metals in soil and sediments $[8,25,26]$. The formulas for the potential ecological risk index were modified as follows by Rafiei et al [27]:

$$
C_{f}^{i}=C_{D}^{i} / C_{R}^{i} ; C_{D}=\sum_{i=1}^{n} C_{f}^{i} ; E_{r}^{i}=T_{r}^{i} \times C_{r}^{i} ; R I=\sum_{1=0}^{n} E_{r}^{i} ;
$$

where $C_{f}^{i}, C_{D}^{i}$, and $C_{R}^{i}$ refer to the contamination factors, the mean concentration of the measured contamination, and the background reference level, respectively. $C_{d}$ is the degree of contamination. $E_{r}^{i}$ is the potential ecological risk factor for the given substance $i$. $T_{r}^{i}$ denotes the 'toxic response' factor for the individual substance (eg $\mathrm{Cd}=30, \mathrm{Cr}=10$, $\mathrm{Cu}=5, \mathrm{~Pb}=5, \mathrm{Zn}=5$ and $\mathrm{As}=2$ ) [8]. Finally, $R I$ is the integrated potential risk index of metals [28].

Sediments were classified into the following groups according to their degree of contamination: $C_{f}^{i}<1$ or $C_{d}<8$ : low degree of contamination; $1 \leq C_{f}^{i}<3$ or $8 \leq C_{d}<16$ : moderate degree of contamination; $3 \leq C_{f}^{i}<6$ or $16 \leq C_{d}<32$ : considerable degree of contamination; $C_{f}^{i} \geq 6$ or $C_{d} \geq 32$ : very high degree of contamination indicating serious anthropogenic pollution [29].

$E_{r}^{i}$ and $R I$ values were classified into the following groups to describe the risk factor: $E_{r}^{i}<40$ or $R I<150$ : low potential ecological risk; $40 \leq E_{r}^{i}<80$ or $150 \leq R I<300$ : moderate potential ecological risk; $80 \leq E_{r}^{i}<160$ or $300 \leq R I<600$ : considerable potential ecological risk; $160 \leq E_{r}^{i}<320$ : high potential ecological risk; $E_{r}^{i} \geq 320$ or $R I \geq 600$ : very high potential ecological risk [29].

Generally speaking, EF and PCA were used to track the sources of heavy metals and restructure the pollution progress, while ERI was employed to assess the potential ecological risk assessment, ie different metrics had different emphasis or purposes.

\section{Statistical analysis}

Unless otherwise stated, all experiences were carried out in triplicates and means and standard deviations were reported. Statistical calculations in this study were performed using the SPSS 13.0 software for Windows (SPSS Inc., USA).

\section{Results}

\section{Physical and chemical properties of overlying water and sediments}

The basic physical and chemical properties of overlying water from sampling sites of the riverine wetland are shown in Table 1. It can be seen that the water presented 
alkalescence and possessed high DO concentration as well as low ORP. The concentrations of $\mathrm{NH}_{4}{ }^{+}, \mathrm{NO}_{3}{ }^{-}, \mathrm{TN}, \mathrm{PO}_{4}{ }^{3-}$ and $\mathrm{TP}$ of overlying water from the sampling sites are listed in Table 1. Apart from $\mathrm{NO}_{3}{ }^{-}$and $\mathrm{PO}_{4}{ }^{3-}$, the concentrations of $\mathrm{NH}_{4}{ }^{+}, \mathrm{TN}$, and $\mathrm{TP}$ were high and approximately $2.7,3.5$, and 2 orders of the reference values listed in National Grade $\mathrm{V}$ value in the environmental guideline of national quality standards for surface waters in China (GB3838-2002). Furthermore, according to reference values (RV) of trophic level classification proposed by Vollenweider and Kerekes [30], the study area can be classified as eutrophic.

Table 1

The basic physicochemical indexes in overlying water from sampling sites

\begin{tabular}{|c|c|c|c|c|c|c|c|c|c|c|c|}
\hline & $\mathbf{T}$ & pH & TDS & ORP & EC & DO & $\mathrm{NH}_{4}^{-}$ & $\mathrm{NO}_{3}^{-}$ & $\mathbf{T N}$ & $\mathrm{PO}_{4}{ }^{3-}$ & TP \\
\hline & {$\left[{ }^{\circ} \mathbf{C}\right]$} & & {$\left[\mathrm{g} \cdot \mathrm{dm}^{-3}\right]$} & {$[\mathrm{mV}]$} & {$\left[\mathrm{ms}^{\cdot} \mathrm{cm}^{-1}\right]$} & \multicolumn{6}{|c|}{$\left[\mathrm{mg} \cdot \mathrm{dm}^{-3}\right]$} \\
\hline Mean & 17.35 & 8.34 & 0.667 & -12.00 & 1.04 & 9.51 & 5.4 & 0.8 & 7.0 & 0.30 & 0.84 \\
\hline Std. Deviation & 0.04 & 0.03 & 0.001 & 4.08 & 0.00 & 0.08 & 0.3 & 0.4 & 0.6 & 0.09 & 0.18 \\
\hline
\end{tabular}

Illustrated in Figure 2 are the values of TOC, TN, and $\mathrm{C} / \mathrm{N}$ ratio for sediment cores from the sampling sites. As indicated in the figure, the mean concentrations of TOC and TN varied from $0.90 \pm 0.06$ to $9.70 \pm 0.17 \%$ and $0.050 \pm 0.003$ to $0.96 \pm 0.021 \%$, respectively, while $\mathrm{C} / \mathrm{N}$ fluctuated from $10.1 \pm 0.06$ to $20.1 \pm 059$. In general, TOC and TN showed a tendency to increase from the bottom to upper layer of the sediment cores. Conversely, $\mathrm{C} / \mathrm{N}$ concentrations decreased slightly from bottom to the top of sediment cores.

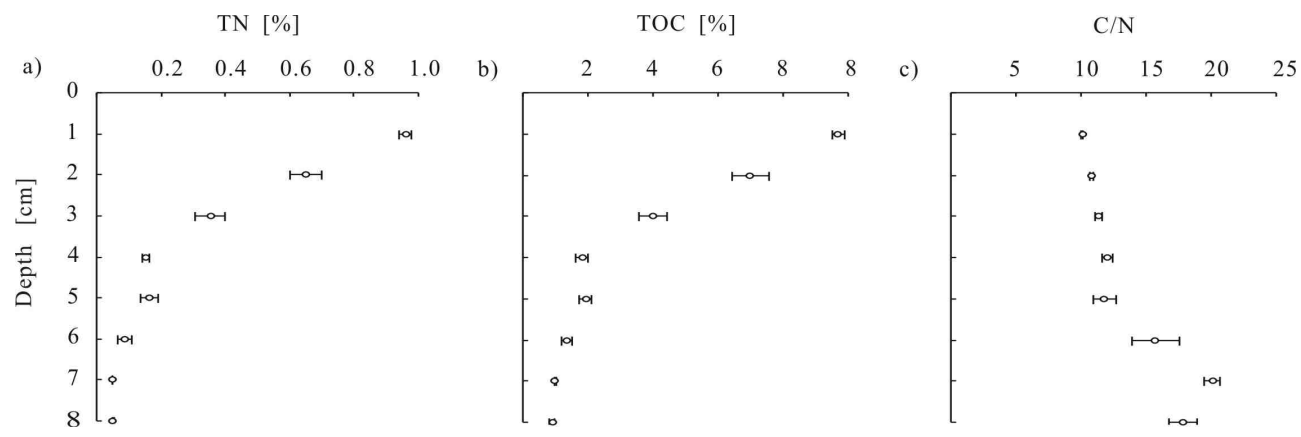

Fig. 2. TOC and $\mathrm{TN}$ concentrations and $\mathrm{C} / \mathrm{N}$ on sediment profiles from sampling sites

\section{Enrichment factors and PCA analysis}

As shown in Figure 3, similar to the variation in TOC, the concentrations of heavy metals in sediment cores significantly increased from the bottom to the cores' top layer. Zn, $\mathrm{Cr}, \mathrm{Cu}, \mathrm{As}, \mathrm{Cd}$, and $\mathrm{Pb}$ concentrations varied from $51.0 \pm 3.0$ to $552.0 \pm 8.1 \mathrm{mg} \cdot \mathrm{kg}^{-1}$, $45.7 \pm 0.3$ to $100.3 \pm 1.5 \mathrm{mg} \cdot \mathrm{kg}^{-1}, \quad 17.6 \pm 1.0$ to $208.8 \pm 3.1 \mathrm{mg} \cdot \mathrm{kg}^{-1}, 2.6 \pm 0.1$ to $4.9 \pm 0.6 \mathrm{mg} \cdot \mathrm{kg}^{-1}, 0.1 \pm 0.0$ to $0.90 \pm 0.02 \mathrm{mg} \cdot \mathrm{kg}^{-1}$, and $16.2 \pm 0.2$ to $45.9 \pm 1.2 \mathrm{mg} \cdot \mathrm{kg}^{-1}$, respectively (Fig. 3a,b). The maximum values for metals were approximately 6.8, 1.4, 7.4, 1.3, 4.8, and 1.9-fold than the lowest values, respectively. To definitely discriminate the sources and contamination degrees of the heavy metals, $E F$ values for different depths of sediment cores were calculated and are illustrated in Figure 3c,d. Generally speaking, 
$E F>1$ is taken to reflect higher levels of anthropogenic pollution, and $E F<1$ denotes a crustal source for the elements in sediment [17, 31]. Figure 3c,d showed that $E F$ values ranged from 1.1, 2.0, 1.0, 2.5, 1.9, and 1.3 to 7.5, 2.8, 8.1, 3.2, 8.6, and 2.3 for $\mathrm{Zn}, \mathrm{Cr}, \mathrm{Cu}$, $\mathrm{As}, \mathrm{Cd}$, and $\mathrm{Pb}$, respectively. The maximum values were approximately $6.8,1.4,7.4,1.3$, 4.8, and 1.9-fold of the minimum, respectively. Similarly, the $E F$ displayed an increasing tendency from bottom layer upwards, especially for $\mathrm{Zn}, \mathrm{Cu}$, and $\mathrm{Cd}$.

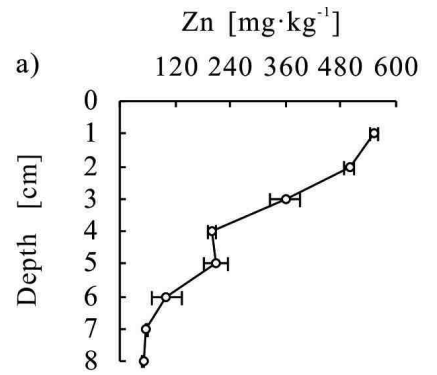

As $\left[\mathrm{mg} \cdot \mathrm{kg}^{-1}\right]$

b) $\quad \begin{array}{llllll}1.2 & 2.4 & 3.6 & 4.8 & 6.0\end{array}$

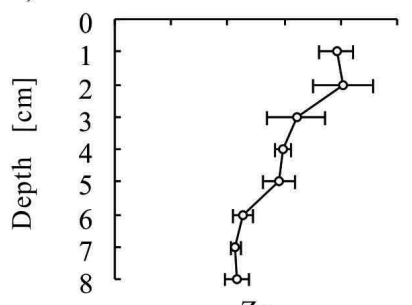

$\mathrm{Zn}$

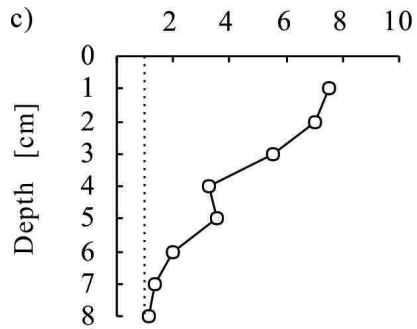

As
Cr $\left[\mathrm{mg} \cdot \mathrm{kg}^{-1}\right]$

$\begin{array}{llllll}30 & 60 & 90 & 120 & 150\end{array}$

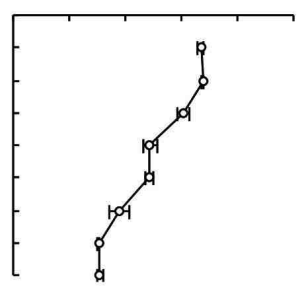

$\mathrm{Cd}\left[\mathrm{mg} \cdot \mathrm{kg}^{-1}\right]$

$\begin{array}{lllll}0.2 & 0.4 & 0.6 & 0.8 & 1.0\end{array}$

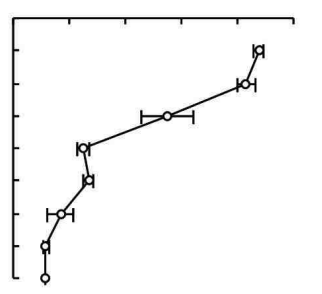

$\mathrm{Cr}$

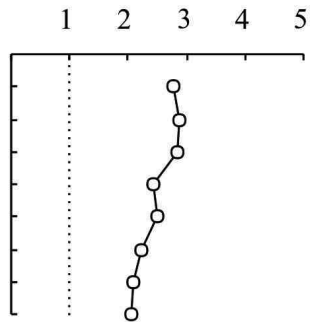

$\mathrm{Cd}$
$\mathrm{Cu}\left[\mathrm{mg} \cdot \mathrm{kg}^{-1}\right]$

$50 \quad 100150200250$

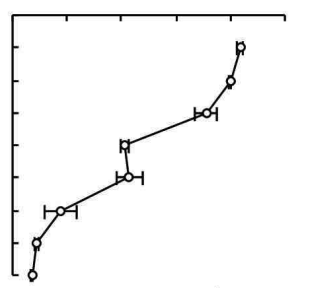

$\mathrm{Pb}\left[\mathrm{mg} \cdot \mathrm{kg}^{-1}\right]$

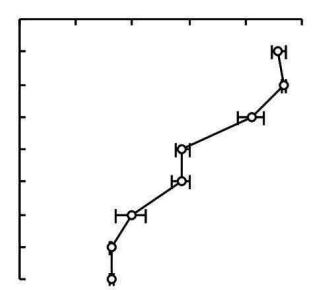

$\mathrm{Cu}$

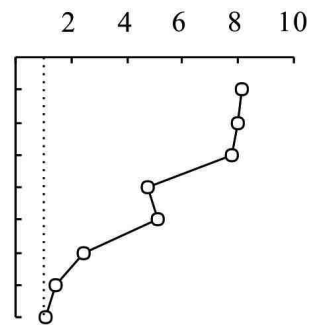

$\mathrm{Pb}$

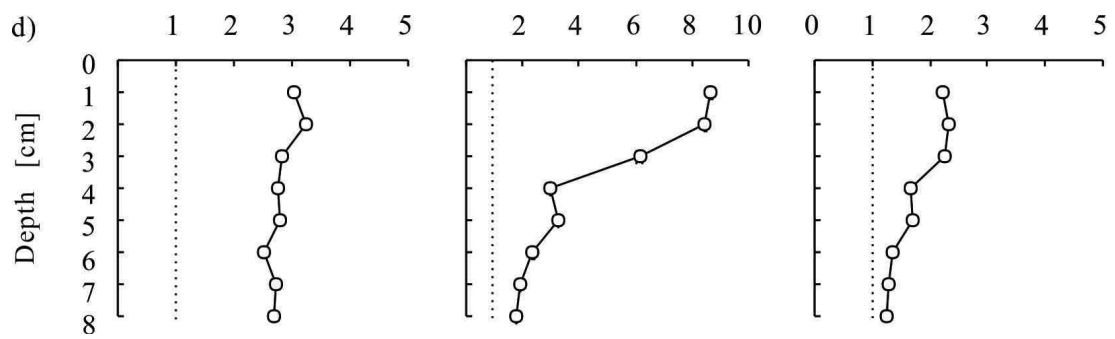

Fig. 3. Variation of concentrations and $E F$ values of $\mathrm{Zn}, \mathrm{Cr}, \mathrm{Cu}, \mathrm{As}, \mathrm{Cd}$ and $\mathrm{Pb}$ in different depth of sediment cores from riverine wetland (dashed lines, $E F=1$ ): a,b) concentrations of heavy metals; c,d) $E F$ values 
Rotated component matrix, eigenvalues and factor loadings after varimax rotation (PC extracted 2 factors) ${ }^{\mathrm{a}}$

\begin{tabular}{|c|c|c|c|c|c|c|c|}
\hline \multirow{2}{*}{ Parameters } & \multicolumn{2}{|c|}{ Component } & \multirow{2}{*}{ Communalities } & \multirow{2}{*}{ Components } & \multicolumn{3}{|c|}{ Initial eigenvalues } \\
\hline & 1 & 2 & & & Total & $\%$ of variance & Cumulative \% \\
\hline $\mathrm{Zn}$ & 0.806 & 0.579 & 0.984 & 1 & 5.589 & 93.157 & 93.157 \\
\hline $\mathrm{Cr}$ & 0.899 & 0.425 & 0.989 & 2 & 0.320 & 5.327 & 98.484 \\
\hline $\mathrm{Cu}$ & 0.901 & 0.423 & 0.991 & 3 & 0.070 & 1.161 & 99.645 \\
\hline As & 0.423 & 0.900 & 0.989 & 4 & 0.018 & 0.301 & 99.946 \\
\hline $\mathrm{Cd}$ & 0.728 & 0.659 & 0.964 & 5 & 0.003 & 0.053 & 100.000 \\
\hline $\mathrm{Pb}$ & 0.859 & 0.503 & 0.992 & 6 & 0.000 & 0.000 & 100.000 \\
\hline
\end{tabular}

${ }^{\text {a }}$ Kaiser-Meyer-Olkin Measure of Sampling Adequacy of 8 was 0.503 , Bartlett's Test of Sphericity with Approx. Chi-Square come up to 94.485 and significance level of 0.000 which was significant at $p<0.01$ level demonstrated the data in Table 2 was suit to factor analysis. Only the first two eigenvectors have been retained to suffice reflecting majority of information of all data.

Displayed in Table 2 are the factor loadings after varimax rotation (a change of coordinates that maximizes the sum of the variances). Eigenvalues of eight eigenvectors are listed. Generally speaking, the varimax loadings $>0.71$ are commonly regarded as excellent, while $<0.32$ is very poor [32]. Furthermore, all principal factors extracted from the variables were retained with eigenvalues $<1.0$ [16]. The results of the PCA analyses of heavy metals in sediment cores from the riverine wetland showed that two components accounted for about $98.5 \%$ of the total variance in the data matrix. Two relatively independent behaviors of heavy metals were grouped based on PCA results on the whole. Component 1 accounted for $93.2 \%$ of the total variance and was dominated by $\mathrm{Zn}, \mathrm{Cr}, \mathrm{Cu}$, $\mathrm{Cd}$, and $\mathrm{Pb}$. Component 2 was dominated by As and occupied $5.3 \%$ which was only a small amount of the total variance.

\section{Ecological risk analysis}

The values of $C_{f}$ and $E_{f}$ for different depths of sediments from a riverine wetland are illustrated in Figure 4. As comprehensive variables, $C_{f}$ and $E_{f}$ were drawn using mean values without standard deviation. Obviously, all the metals displayed the growth tendency from the bottom to upper layer of the sediment cores. In general, $\mathrm{Zn}, \mathrm{Cu}$, and $\mathrm{Cd}$ increased more drastically than $\mathrm{Cr}, \mathrm{As}$, and $\mathrm{Pb}$. The maximum values of $C_{f}$ and $E_{r}$ for $\mathrm{Zn}, \mathrm{Cr}, \mathrm{Cu}, \mathrm{As}, \mathrm{Cd}$, and $\mathrm{Pb}$ were 10.8, 2.2, 11.9, 1.8, 7.7, and 2.8-fold greater than their minimum values, respectively. It was remarkable that from about the $6 \mathrm{~cm}$ layer, the $E_{r}$ values of $\mathrm{Cd}$ illustrated in Figure 4d exceeded 40, which indicates a moderate potential ecological risk until high potential ecological risk from the bottom upwards according to Håkanson [24].

Figure 5 displays the variations in $C_{d}$ and $R I$ values for $\mathrm{Zn}, \mathrm{Cr}, \mathrm{Cu}, \mathrm{As}, \mathrm{Cd}$, and $\mathrm{Pb}$ in sediment cores. It can be seen in the figure that $C_{d}$ and $R I$ values increased from bottom to surface of sediment cores and particularly significantly from about the $4 \mathrm{~cm}$ depth layer. The highest values of $C_{d}$ and $R I$ were approx. 5.2 and 5.8-fold greater than the lowest values, respectively. The maximum values of $C_{d}$ and $R I, 33.4$ and 366.3 , respectively, were observed near the top layer of the sediment cores, and the minimum values, 6.5 and 63.5 , respectively, were measured at the bottom of sediment cores. 

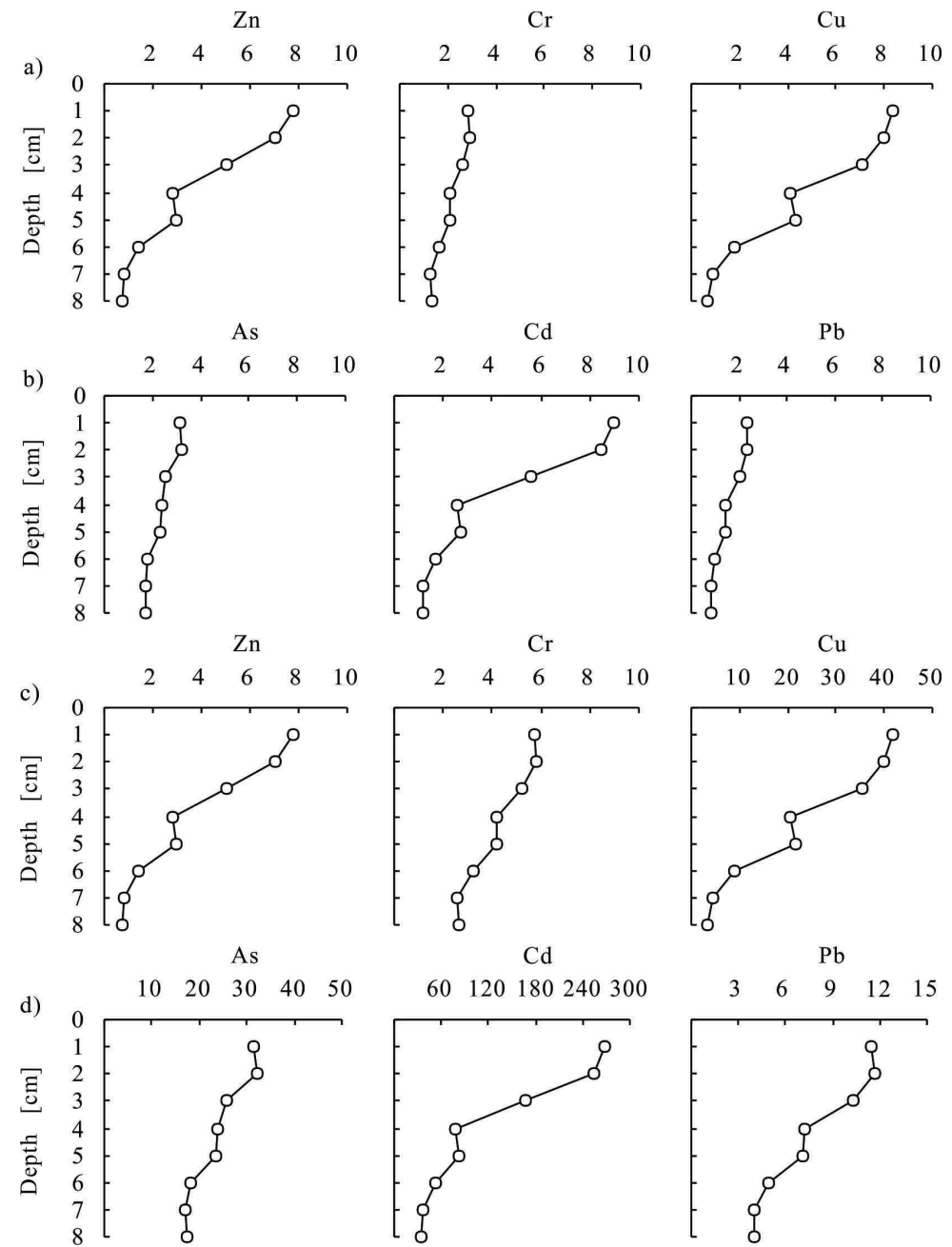

$\mathrm{Cd}$
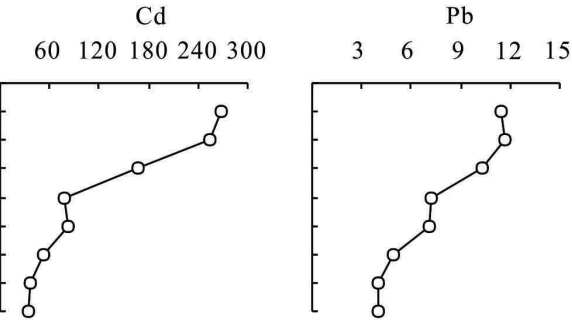

Fig. 4. Variation of $C_{f}$ and $E_{r}$ values of heavy metals in sediments from different depth of riverine wetland: a, b) $C_{f}$; c,d) $E_{r}$

$C_{d}$

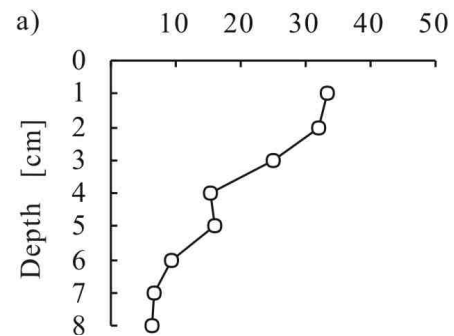

RI

b) $\quad 80 \quad 160 \quad 240 \quad 320 \quad 400$

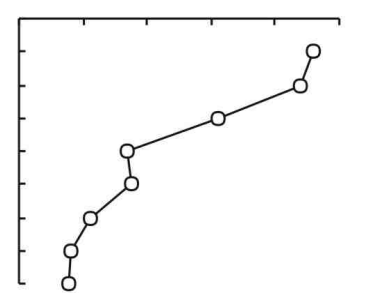

Fig. 5. Variation of $C_{d}$ and $R I$ and values of heavy metals in sediments from different depth of riverine wetland 


\section{Discussion}

The sampling sites were located near a sewage drainage outlet from the Chemical Industrial Park of Zhengzhou City. The outlet receives a great quantity of industrial effluent and domestic sewage with great amounts of contamination, including nutrients and heavy metals. A part of the metals deposited in the sediments are absorbed by aquatic plants such as Paspalum distichum, the dominating aquatic plant, and plankton. Residual bodies of aquatic organism deposited into sediments and bring about the enrichment of heavy metals owning to the increase of organic matter [33]. The origin of sedimentary organic matter can be distinguished by the $\mathrm{C} / \mathrm{N}$ ratio of compositions of different aquatic plants. Relatively low $\mathrm{C} / \mathrm{N}$ ratios ranging from 4 to 10 can indicate internal organic matter derived from terrigenous detritus and autogenetic algae debris, whereas the large amount of cellulose-rich and protein-poor vascular aquatic plants are the main contributors to organic matter and are responsible for $\mathrm{C} / \mathrm{N}$ ratios greater than 20 [34]. The sampling locations in this research were mainly covered with silt clay [35]. Relatively high TOC concentrations $(9.70 \pm 0.17 \%)$ may be attributed to the enrichment of fine grained sediments in the riverine wetland. Heavy metals tend to be absorbed by organic materials due to the large specific surface area [27]. It can be seen that the $\mathrm{C} / \mathrm{N}$ ratios of different depths of the sediment cores from the riverine wetland varied from 10.1 to 20.1 , suggesting that organic matter originated principally from aquatic plants. An increase in metals' concentrations may not indicate a temporally increasing trend in metal input to the aquatic system, but may occur because the metals are easier bound to the organic matter. Furthermore, the significant positive correlations were observed between TOC and metals, ie, $\mathrm{Zn}, \mathrm{Cr}, \mathrm{Cu}, \mathrm{As}, \mathrm{Cd}$, and $\mathrm{Pb}(\mathrm{R}=0.959,0.873,0.885$, $0.910,0.973$ and $0.893, p<0.01$, respectively) (Table 3 ) and give evidence of that the metals tend to be adsorbed by the organic matter. The positive correlations, meanwhile, indicate that the ecosystem of the wetland was exposed to potential ecological risk for heavy metals.

Person correlation coefficient matrix between different pairs of variables

\begin{tabular}{|c|c|c|c|c|c|c|c|}
\hline & TOC & Zn & Cr & Cu & As & Cd & Pb \\
\hline TOC & 1.000 & & & & & & \\
\hline $\mathrm{Zn}$ & $0.959^{* *}$ & 1.000 & & & & & \\
\hline $\mathrm{Cr}$ & $0.873^{* *}$ & $0.974^{* *}$ & 1.000 & & & & \\
\hline $\mathrm{Cu}$ & $0.885^{* *}$ & $0.979^{* *}$ & $0.996^{* *}$ & 1.000 & & & \\
\hline $\mathrm{As}$ & $0.910^{* *}$ & $0.980^{* *}$ & $0.977^{* *}$ & $0.970^{* *}$ & 1.000 & & \\
\hline $\mathrm{Cd}$ & $0.973^{* *}$ & $0.991^{* *}$ & $0.944^{* *}$ & $0.951^{* *}$ & $0.961^{* *}$ & 1.000 & \\
\hline $\mathrm{Pb}$ & $0.893^{* *}$ & $0.983^{* *}$ & $0.996^{* *}$ & $0.997^{* *}$ & $0.977^{* *}$ & $0.963^{* *}$ & 1.000 \\
\hline
\end{tabular}

** Correlation is significant at the 0.01 level (2-tailed)

Proximate $E F$ values and being classed into the same parameter group in PCA analysis suggested that $\mathrm{Zn}, \mathrm{Cr}, \mathrm{Cu}, \mathrm{Cd}$, and $\mathrm{Pb}$ had analogous sources and/or similar environmental geochemistry characteristic. $E F$ values greater than 1 reflect relatively high anthropogenic sources of these metals. The effluents from the neighboring industries and municipal sewage as well as domestic sewage might have contributed substantial loads via sewage outlets and overland runoff flowing through the industrial park and agricultural region. $\mathrm{Zn}, \mathrm{Cr}, \mathrm{Cu}, \mathrm{Cd}$, and $\mathrm{Pb}$ were used as stabilizers and additives of synthetic rubber and polymer of vinyl 
chloride manufacturer at the chemical park of Zhengzhou City. Cr enrichment might came primarily from the leather tanning companies, $\mathrm{Cu}$ and $\mathrm{Zn}$ were also likely connected to the influence of numerous electroplating companies in many surrounding towns situated at both sides of the Suoxu River [36]. From $4 \mathrm{~cm}$ depth of the sediment cores the remarkably increase in $\mathrm{EF}$ values indicated that the pollution of the riverine wetland was accelerated in recent years. Factor loadings diversity obtained from PCA indicated that the heavy metals have different sources. Owning to steadier values of $E F$ relative to other metals in sediment cores, it was speculated that As principally derived from the use of agricultural pesticide chemicals, mining, smelting, and fuel burning in towns located on the upstream of the River [37-39].

The $C_{f}$ and $E_{r}$ showed moderate contamination from the bottom upward to the $6 \mathrm{~cm}$ layer of sediment cores with low values, whereas remarkable increase upwards meant that the contamination degree of sediments increased over time. The values of $C_{f}>1$ indicated a moderate to very high contamination of substances in the riverine wetland. Owning to stronger potency factors, Cd possessed larger $E_{r}$ values than other metals from the bottom to upper layers of the sediment cores, suggesting that $\mathrm{Cd}$ presents the highest potential ecological risk. So the riverine wetland was exposed to highest contamination degree for $\mathrm{Cd}$ in sediment cores. Finally, the contamination degree $\left(C_{d}\right)$ of individual metals decreased in the order: $\mathrm{Cd}>\mathrm{Cu}>\mathrm{As}>\mathrm{Pb}>\mathrm{Zn}>\mathrm{Cr}$.

Even the „toxic response” factors for $\mathrm{Cu}, \mathrm{As}, \mathrm{Pb}, \mathrm{Zn}$, and $\mathrm{Cr}$ were much lower than that for Cd [29]. Relatively low values of $C_{d}$ indicated that sediments had no significant potential ecological risk as far as $\mathrm{Pb}, \mathrm{Cr}$, and $\mathrm{As}$ are concerned, while $\mathrm{Cd}$ exerted the highest potential ecological risk. Based on the potential ecological risk assessment for multiple-factor, integrated $R I$ values can provide a good resolution for the investigated sediments. Generally speaking, sediments from the bottom upward to about the $6 \mathrm{~cm}$ depth layer were categorized as low ecological risk and moderate ecological risk from $5 \mathrm{~cm}$ depth layer upwards, subsequently, considerable ecological risk from $4 \mathrm{~cm}$ depth to top layer (Fig. 5).

\section{Conclusions}

The concentrations of $\mathrm{Zn}, \mathrm{Cr}, \mathrm{Cu}, \mathrm{As}, \mathrm{Cd}$, and $\mathrm{Pb}$ in sediment cores obtained from a riverine wetland located near the Suoxu River, a tributary of the Huaihe River Watershed, China, presented significant regularity from the cores' bottom to the upper layer and showed the deterioration of environmental quality that should be attributed to constant emission of pollutants. The application of principal component analysis (PCA) and enrichment factors (EF) enabled us to find that the considerable loading of the heavy metals might primarily result from the inflow of contaminated water from an industrial park and agricultural region. Component 1 was dominated by $\mathrm{Zn}, \mathrm{Cr}, \mathrm{Cu}, \mathrm{Cd}$, and $\mathrm{Pb}$, and accounted for $98.5 \%$ of the total variance. Component 2 was dominated by As. Metals' relatively high EF values indicated that they were probably discharged into water and deposited into sediments from similar pollution sources. High concentrations and $E F$ values for metals showed that the anthropogenic pollutants had increased sharply in recent years and reflect a continuous development of industry and agriculture and a corresponding dramatic deterioration of the environment in the region. 
Based on assessment of ecological risk for individual metals in sediment cores, Cd had the highest potential ecological risk and was most likely to cause adverse effects. Furthermore, based on the integrated potential ecological risk assessment for multiple-factor, integrated $R I$ values for $\mathrm{Zn}, \mathrm{Cr}, \mathrm{Cu}, \mathrm{As}, \mathrm{Cd}$, and $\mathrm{Pb}$ indicated that sediments from the bottom upward to about $6 \mathrm{~cm}$ depth layers possessed low ecological risk and moderate ecological risk from 5 to $4 \mathrm{~cm}$ depth layer, but considerable ecological risk from $4 \mathrm{~cm}$ depth to top layer of sediment from riverine wetland, which demonstrated the continuous deterioration of environmental quality.

\section{Acknowledgements}

This research was supported by the Major Science and Technology Program for Water Pollution Control and Treatment (2012ZX07204-004) and the Major Science and Technology Program for Water Pollution Control and Treatment (2012ZX07204-001-004), A Project Funded by the Priority Academic Program Development of Jiangsu Higher Education Institutions (PAPD), and The Startup Foundation for Introducing Talent of NUIST (2014r022).

\section{References}

[1] Rodrigues A, Cunha L, Amarala A, Medeiros J, Garcia P. Sci Total Environ. 2008;406:116-122. DOI: 10.1016/j.scitotenv.2008.07.069.

[2] Khairy MA, Kolb M, Schmidt C, Zachmann DW, Mostafa AR, El-Fiky AA, et al. Clean-Soil Air Water. 2010;38:1184-1193. DOI: 10.1002/clen.201000145.

[3] Naji A, Ismail A. Aquat Ecosyst Health. 2012;15:287-293. DOI: 10.1080/14634988.2012.706108.

[4] Kaushik A, Kansal A, Meena S, Kumari S, Kaushik CP. J Hazard Mater. 2009;164:265-270. DOI: 10.1016/j.jhazmat.2008.08.031.

[5] Rashed MN. Environ Internat. 2001;27:27-33. DOI: 10.1016/S0160-4120(01)00050-2.

[6] Adhikari S, Ghosh SL, Giri BS, Ayyappan GS. Ecotox Environ Safe. 2009;72:1242-1248. DOI: 10.1016/j.ecoenv.2008.10.011.

[7] Shen J, Liu EF, Zhu YX, Hu SY, Qu WC. Hydrobiologia. 2007;581:141-150. DOI: 10.1007/s10750-006-0523-3.

[8] Yang ZF, Wang Y, Shen ZY, Niu JF, Tang ZW. J Hazard Mater. 2009;166:1186-1194. DOI: 10.1016/j.jhazmat.2008.12.034.

[9] Jin Q, Jiang QN, Wu F, Li X, Deng XZ. Clean-Soil Air Water. 2013;4:370-376. DOI: 10.1002/clen.201200065.

[10] Zeng YY, Huang XP, Ye F, Tian L. Aquat Ecosyst Health. 2012;15:185-191. DOI: 10.1080/14634988.2012.688695.

[11] Sun JH, Feng JL, Liu Q, Li Q. J Hazard Mater. 2010;184:141-146. DOI: 10.1016/j.jhazmat.2010.08.016.

[12] Kalbitz K, Wennrich R. Sci Total Environ. 1998;209:27-39. DOI: 10.1016/S0048-9697(97)00302-1.

[13] Marchand L, Mench M, Jacob DL, Otte ML. Environ Pollut. 2010;158:3447-3461. DOI: 10.1016/j.envpol.2010.08.018.

[14] Yuan HZ, Liu EF, Pan W, An SQ. Pol J Environ Stud. 2014;23:541-549.

[15] Baptista Neto JA, Smith BJ, Mcallister JJ. Environ Pollut. 2000;109:1-9. DOI: 10.1016/S0269-7491(99)00233-X.

[16] Mil-Homens M, Stevens RL, Abrantesa F, Cato I. Cont Shelf Res. 206;26:1184-1205. DOI: 10.1016/j.csr.2006.04.002.

[17] Glasby GP, Szefer P, Geldon J, Warzocha J. Sci Total Environ. 2004;330:249-269. DOI: 10.1016/j.scitotenv.2004.04.004.

[18] Esen E, Kucuksezgin F, Uluturhan E. Environ Monit Assess. 2010;160:257-266. DOI: 10.1007/s10661-008-0692-9.

[19] Ergin M, Saydam C, Bastürk Ö, Yörük R. Chem Geol. 1991;91:269-285. DOI: 10.1016/0009-2541(91)90004-B. 
[20] Filgueiras AV, Lavilla I, Bendicho C. Sci Total Environ. 2004;44:115-129. DOI: 10.1016/j.scitotenv.2004.03.038.

[21] Zaharescu DG, Hooda PS, Soler AP, Fernandez J, Burghelea CI. Sci Total Environ. 2009;407:3546-3553. DOI: $10.1016 /$ j.scitotenv.2009.02.026.

[22] Iqbal J, Shah HM. Hum Ecol Risk Assess. 2013;19:1553-1543. DOI: 10.1080/10807039.2012.716681.

[23] Han FX, Su Y, Monts DL, Plodinec MJ, Banin A, Triplett GE. Naturwissenschaften. 2003;90:395-401. DOI: $10.1007 / \mathrm{s} 00114-003-0451-2$.

[24] Håkanson L. Water Res. 1980;14:975-1001. DOI: 10.1016/0043-1354(80)90143-8.

[25] Fernandes HM. Environ Pollut. 1997;97:317-325. DOI: 10.1016/S0269-7491(97)00004-3.

[26] He JJ, Zhang HM, Zhang H, Guo X, Song MW, Zhang JH, et al. Ecol Chem Eng S. 2014;21:189-199. DOI: 10.2478/eces-2014-0015.

[27] Rafiei B, Ghomi FA, Ardebili L, Sadeghifar M, Sharifi SHK. Soil Sediment Contam. 2012;21:768-787. DOI: $10.1080 / 15320383.2012 .678953$.

[28] Luo W, Lu YL, Wang TY, Hu WY, Jiao WT, Naile JE, et al. Ambio. 2010;39:367-375. DOI: 10.1007/s13280-010-0077-5.

[29] Zhang LW, Shao HB. Clean-Soil Air Water. 2013;41:878-882. DOI: 10.1002/clen.201200565.

[30] Havens KE, Fukushima T, Xie P, Iwakuma T, James RT, Takamura N, et al. Environ Pollut. 2001;111:263-272. DOI: 10.1016/S0269-7491(00)00074-9.

[31] García JH, Li WW, Arimoto R, Okrasinski R, Greenlee J, Walton J, et al. Sci Total Environ. 2004;325:95-112. DOI: 10.1016/j.scitotenv.2003.11.011.

[32] Yuan HZ, Shen J, Liu EF, Wang JJ, Meng XH. Environ Geochem Health. 2011;33:67-81. DOI: 10.1007/s10653-010-9323-9.

[33] Breault RF, Colman JA, Aiken GR, Mcknight D. Environ Sci Technol. 1996;30:3477-3486. DOI:10.1021/es9601301.

[34] Meyers PA, Ishiwatari AR. Org Geochem. 1993;20:869-900. DOI: 10.1016/0146-6380(93)90100-P.

[35] Yuan HZ, Pan W, Ren LJ, Liu EF, Shen J, Geng QF, et al. Int J Phytoremediat. 2015;17:215-221. DOI: 10.1080/15226514.2013.876969.

[36] Qu WC, Mike D, Wang SM. Hydrobiologia. 2001;450:83-91. DOI: 10.1023/A:1017551701587.

[37] Han YM, Du PX, Cao JJ, Posmentier ES. Sci Total Environ. 2006;355:176-186. DOI: 10.1016/j.scitotenv.2005.02.026.

[38] Li CL, Kang SC, Zhang QG. Environ Pollut. 2009;157:2261-2265. DOI: 10.1016/j.envpol.2009.03.035.

[39] Cao HC, Luan ZQ, Wang JD, Zhang XL. Stoch Environ Res Risk A. 2009;23:57-64. DOI: 10.1007/s00477-007-0195-1.

\title{
OCENY RYZYKA EKOLOGICZNEGO ZWIĄZANEGO Z METALAMI CIĘŻKIMI W OSADACH NADRZECZNYCH TERENÓW PODMOKŁYCH ZLEWNI RZEKI HUAIHE, CHINY
}

\begin{abstract}
Abstrakt: Stężenia $\mathrm{Zn}, \mathrm{Cr}, \mathrm{Cu}, \mathrm{As}, \mathrm{Cd}$ i $\mathrm{Pb}$ w rdzeniach osadów pobranych z reprezentatywnych podmokłych terenów nadrzecznych, znajdujących się w zlewni rzeki Huaihe, Chiny, wykazały znaczne wzrosty od dołu do górnej warstwy rdzeni. Zastosowanie analizy głównych składowych (PCA) i czynnika wzbogacania $(E F)$ wykazało, że źródłem metali ciężkich mogą być przede wszystkim zanieczyszczone wody z parku przemysłowego i z obszarów rolniczych regionu. Składowa 1 PCA było zdominowane przez $\mathrm{Zn}, \mathrm{Cr}, \mathrm{Cu}, \mathrm{Cd}$, i Pb, natomiast składowa 2 była zdominowana przez As. Duże stężenia metali i wartości $E F$ wykazały, że antropogenne zanieczyszczenie gwałtownie wzrosło w ostatnich latach i odzwierciedla ciągły rozwój przemysłu i rolnictwa w regionie nadrzecznym, z odpowiednim drastycznym pogorszeniem stanu środowiska ze względu na stałe zanieczyszczenie ściekami. Cd stwarza największe potencjalne ryzyko ekologiczne spośród wszystkich metali rdzeni osadów. Dodatkowo, zintegrowane wartości $R I$ dla wszystkich metali wskazują, że osady tworzyły niskie zagrożenie ekologiczne od dołu do około $6 \mathrm{~cm}$ głębokości rdzeni, umiarkowane ryzyko ekologiczne od około $5 \mathrm{~cm}$ głębokości do góry. Znaczne zagrożenie ekologiczne stwarzają osady od głębokości $4 \mathrm{~cm}$ do warstwy wierzchniej rdzenia, co świadczy o ciągłym pogarszaniu się jakości środowiska w ostatnich latach w tym regionie.
\end{abstract}

Słowa kluczowe: charakterystyka geochemii środowiska, ocena ryzyka ekologicznego, metale ciężkie, osady, teren nadrzeczny podmokły 